\title{
Automated ground-based remote sensing measurements of greenhouse gases at the Białystok site in comparison with collocated in situ measurements and model data
}

\author{
J. Messerschmidt ${ }^{1,{ }^{*}}$, H. Chen ${ }^{2, * *}$, N. M. Deutscher ${ }^{1}$, C. Gerbig ${ }^{2}$, P. Grupe ${ }^{1}$, K. Katrynski ${ }^{4}$, F.-T. Koch ${ }^{2}$, J. V. Lavrič ${ }^{2}$, \\ J. Notholt ${ }^{1}$, C. Rödenbeck ${ }^{2}$, W. Ruhe ${ }^{3}$, T. Warneke ${ }^{1}$, and C. Weinzierl ${ }^{1}$ \\ ${ }^{1}$ Institute of Environmental Physics, University of Bremen, Bremen, Germany \\ ${ }^{2}$ Max Planck Institute for Biogeochemistry, Jena, Germany \\ 3 impres GmbH, Bremen, Germany \\ ${ }^{4}$ AeroMeteoservice, Białystok, Poland \\ *now at: California Institute of Technology, Pasadena, CA, USA \\ ** now at: NOAA-ESRL, Boulder, CO 80305, USA
}

Correspondence to: J. Messerschmidt (janina@caltech.edu)

Received: 14 September 2011 - Published in Atmos. Chem. Phys. Discuss.: 8 December 2011

Revised: 7 April 2012 - Accepted: 16 July 2012 - Published: 1 August 2012

\begin{abstract}
The in situ boundary layer measurement site in Białystok (Poland) has been upgraded with a fully automated observatory for total greenhouse gas column measurements. The automated Fourier Transform Spectrometer (FTS) complements the on-site in situ facilities and FTS solar absorption measurements have been recorded nearly continuously in clear and partially cloudy conditions since March 2009. Here, the FTS measurements are compared with the collocated tall tower data. Additionally, simulations of the Jena $\mathrm{CO}_{2}$ inversion model are evaluated with the Białystok measurement facilities. The simulated seasonal $\mathrm{CO}_{2}$ cycle is slightly overestimated by a mean difference of $1.2 \mathrm{ppm} \pm 0.9 \mathrm{ppm}(1 \sigma)$ in comparison with the FTS measurements. $\mathrm{CO}_{2}$ concentrations at the surface, measured at the tall tower $(5 \mathrm{~m}, 90 \mathrm{~m}, 300 \mathrm{~m})$, are slightly underestimated by $-1.5 \mathrm{ppm},-1.6 \mathrm{ppm}$, and $-0.7 \mathrm{ppm}$ respectively during the day and by $-9.1 \mathrm{ppm},-5.9 \mathrm{ppm}$, and $-1.3 \mathrm{ppm}$ during the night. The comparison of the simulated $\mathrm{CO}_{2}$ profiles with low aircraft profiles shows a slight overestimation of the lower troposphere (by up to $1 \mathrm{ppm}$ ) and an underestimation in near-surface heights until $800 \mathrm{~m}$ (by up to $2.5 \mathrm{ppm}$ ). In an appendix the automated FTS observatory, including the hardware components and the automation software, is described in its basics.
\end{abstract}

\section{Introduction}

Until recently remote sensing measurements of greenhouse gases (GHGs) have not been used in atmospheric inversions to determine $\mathrm{CO}_{2}$ source/sink distributions. Atmospheric inverse transport modeling have traditionally been based on a network of in situ boundary layer measurement sites. However, the surface flux distributions derived from these measurements are limited by the sparse spatial coverage of the sampling sites (Marquis and Tans, 2008) and also by the sensitivity of sink estimates to the assumed vertical model transport. Recent studies (Baker et al., 2006; Stephens et al., 2007; Yang et al., 2007) have shown that atmospheric inverse model results were inconsistent with vertical aircraft profiles and total column measurements due to an incorrect representation of the vertical transport.

It is likely that the use of total column measurements in inverse modeling studies will overcome these problems, as the total column measurements of $\mathrm{CO}_{2}$ are not dependent on vertical transport assumptions. They provide a largely independent piece of information to understand $\mathrm{CO}_{2}$ distributions in addition to in situ boundary layer measurements, because variations in total column measurements are dominated by global flux distributions and local and regional fluxes have only a minor impact (Keppel-Aleks et al., 2012). By integrating total column measurements within surface 
flux inversions, the estimation of the spatial distribution and the temporal variation of the $\mathrm{CO}_{2}$ sources and sinks is expected to be improved (Rayner and O'Brien, 2001; Yang et al., 2007). Of significant importance for the success of the total column measurements is the integration into the existing in-situ observation network. Source-sink estimates derived from total column measurements can be gravely distorted by small systematic biases compared to in-situ measurements (Rayner and O'Brien, 2001). Therefore, a biasfree, spatially dense dataset must be established from satellite total column measurements, carefully calibrated and validated by ground-based total column measurements that are in turn calibrated to in situ standards. At present, satellite missions aim to acquire global coverage via space-based total column measurements (SCIAMACHY - Bovensmann et al., 1999, GOSAT - Morino et al., 2011, OCO-2 - Crisp et al., 2008). The Total Carbon Column Observing Network (TC$\mathrm{CON}$ ) is a worldwide network of high resolution groundbased solar absorption FTSs that was founded in 2004. The individual TCCON sites are operated by various institutions around the world (Deutscher et al., 2010; Geibel et al., 2010; Washenfelder et al., 2006; Wunch et al., 2010). It has been largely used as a calibration and validation resource for satellite measurements (e.g Reuter et al., 2011; Morino et al., 2011), but also provides insights into carbon cycle science (e.g. Keppel-Aleks et al., 2012; Yang et al., 2007).

The FTS group at the Institute of Environmental Physics (IUP) was responsible for upgrading the in situ GHG measurement sites in Białystok (Poland) and Trainou (France) with automated mobile FTS instruments, which are part of the TCCON. These two sites are among the most important sites for GHG in situ measurements in Europe. Currently they are the only European sites with collocated FTS solar absorption measurements and vertical resolved in situ measurements, including tall tower and regular aircraft profiling in the boundary layer. This article introduces the comparison of the Białystok FTS measurements from the first 20 months of operation (March 2009-November 2010) with the collocated in situ boundary layer measurements. Additionally, the Jena $\mathrm{CO}_{2}$ inversion model is evaluated with the available measurement facilities at the Białystok site.

The Białystok site is, like most atmospheric measurement sites, remote from local sources of atmospheric gases. Thus, the local infrastructure is rudimentary, an operator only occasionally on-site and an automation of the measurement system is often desirable (Washenfelder et al., 2006; Deutscher et al., 2010; Geibel et al., 2010). Here, the Białystok automation system is introduced in an appendix with a detailed description of the hardware and automation software. The Trainou system is similar, with only slight adaptation to local conditions (e.g. internet access).

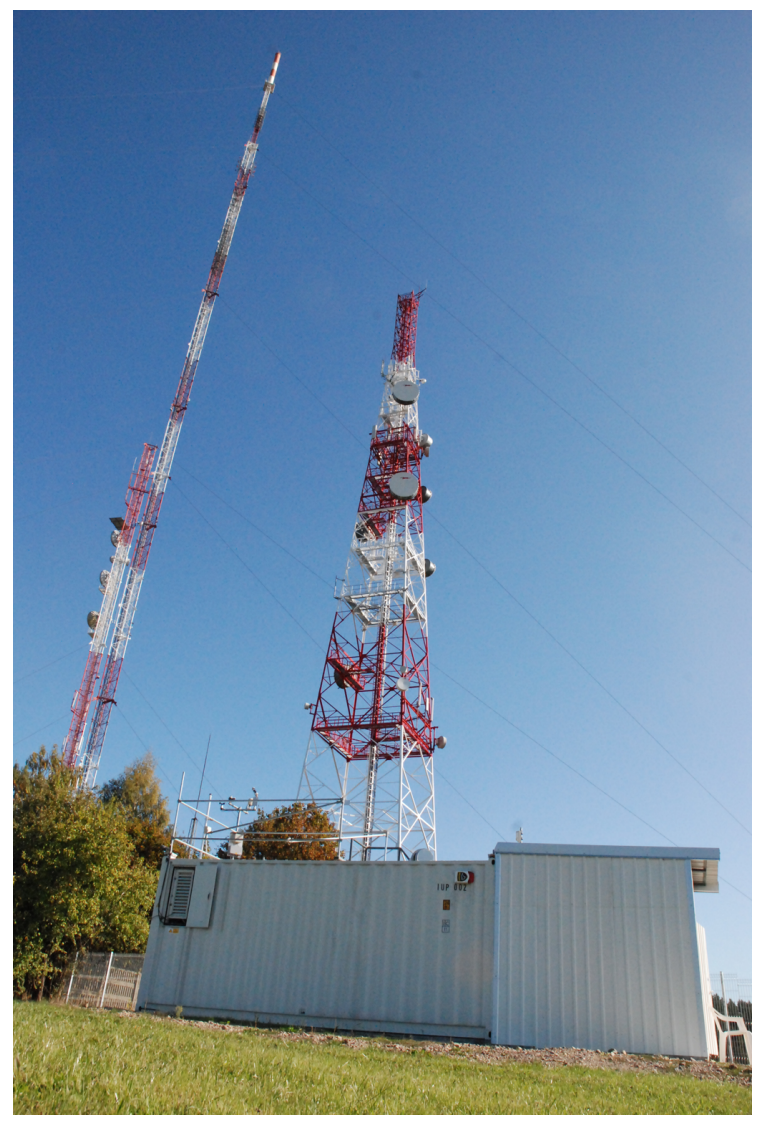

Fig. 1. The Białystok site. In the foreground the FTS observatory with an attached shelter can be seen. In the background the tall tower is visible.

\section{The Białystok FTS instrument}

In the period from August 2007 until February 2009 the FTS automation system was designed and implemented at the IUP in Bremen in collaboration with the company impres $\mathrm{GmbH}$. Different instruments were integrated in one programmable system and the automation strategy and software were developed. In February 2009 the FTS instrument was successfully installed in Białystok and is operated in close cooperation with AeroMeteoService (Poland).

The automated FTS system detects the weather conditions, performs measurements along given day specific tasks, executes self-organized error handling and is entirely remote-controlled. Figure 1 shows the FTS observatory at the Białystok site. In the foreground the container housing the FTS system and an attached shelter can be seen. In the background the tall tower is visible. Figure 2 gives an overview of the general data acquisition. The weather station, installed at the roof of the container, detects the weather conditions. During sunny weather, the hatch cover is open and the solar tracker can point at the sun. The solar beam is directed into the FTS instrument and solar absorption measurements are 


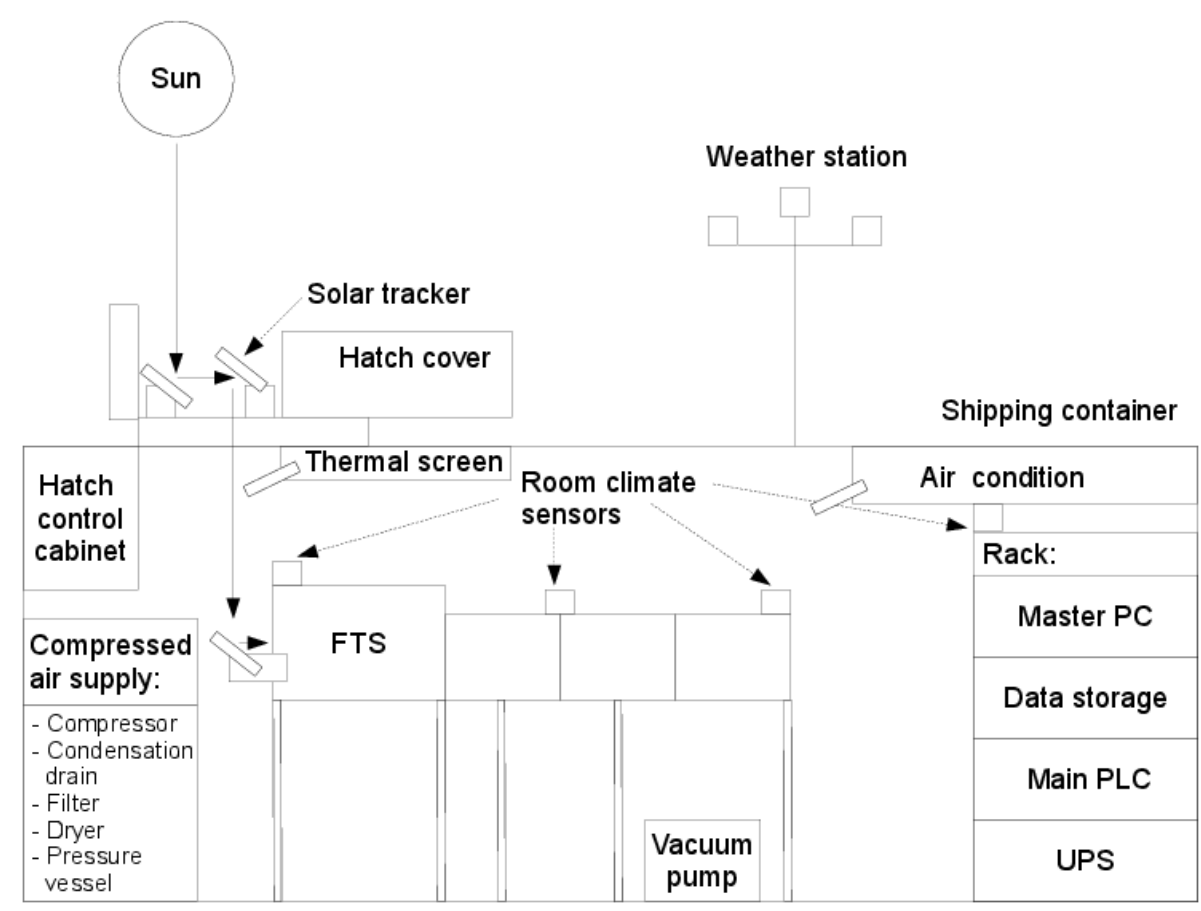

Fig. 2. Schematic of the FTS observatory. The automation system with its hardware for the general data acquisition is depicted. Further details of the components can be found in the Appendix.

taken. Detailed descriptions of the additional hardware are given in the Appendix.

\section{FTS data retrieval}

The Białystok FTS instrument is part of the TCCON and the FTS data are retrieved with the TCCON standard retrieval software. TCCON data products are column-averaged dry-air mole fractions, e.g. $\mathrm{X}_{\mathrm{CO}_{2}}, \mathrm{X}_{\mathrm{CH}_{4}}, \mathrm{X}_{\mathrm{N}_{2} \mathrm{O}}$, and $\mathrm{X}_{\mathrm{CO}}$. TCCON $\mathrm{X}_{\mathrm{CO}_{2}}$ measurements show a precision better than $0.25 \%(\sim 1 \mathrm{ppm})$ (Wunch et al., 2010).

A FTS instrument records interferograms of the incoming solar beam. To calculate the spectra from the interferograms, the SLICE-IPP software developed within the framework of TCCON is used for the Białystok FTS data. The software performs the Fast Fourier transformation and corrects the spectra for solar intensity variations, caused e.g. by passing clouds (Keppel-Aleks et al., 2007).

GFIT, a nonlinear least-squares spectral fitting algorithm, developed by G. C. Toon (Jet Propulsion Laboratory, United States), is used for the retrieval of the trace gas column amounts from the measured spectra (Wunch et al., 2011). In the software an initial vertical profile of gas mole fractions, the a priori profile, is assumed. The tropospheric portion of the a priori $\mathrm{CO}_{2}$ profile is based on an empirical model fitting GLOBALVIEW $\mathrm{CO}_{2}$ data (GLOBALVIEW$\mathrm{CO} 2,2011)$. The day and site specific tropopause height is determined from the National Centers for Environmental Prediction/National Center for Atmospheric Research
(NCEP/NCAR) reanalysis data. The stratospheric a priori $\mathrm{CO}_{2}$ decreases with altitude above the tropopause height, depending on the age of the air, based on measurements of Andrews et al. (2001). The site and day specific $\mathrm{CO}_{2}$ a priori profiles are calculated with meteorological data, e.g. altitude, pressure, temperature and water profiles, taken from NCEP/NCAR reanalysis data interpolated to local noon for the day and to the site latitude and longitude. The a priori profile, along with line parameters e.g. of the HITRAN database (Rothman et al., 2009) and the modeled atmospheric data, are used to calculate a theoretical spectrum. The best fit to the measured spectrum is achieved by scaling the a priori gas profile. The retrieved profile is integrated and the column-averaged dry-air mole fraction (DMF), e.g. $\mathrm{X}_{\mathrm{CO}_{2}}$, is calculated from the retrieved column amount by

$\mathrm{X}_{\mathrm{CO}_{2}}=\frac{1 e 6 \cdot \text { column }_{\mathrm{CO}_{2}}}{\frac{\text { column }_{\mathrm{O}_{2}}}{0.2095}}$

$\mathrm{X}_{\mathrm{CO}_{2}}$ is expressed in $\mu \mathrm{mol} \mathrm{mol}^{-1}$, commonly referred to as parts per million [ppm].

Taking the ratio of the atmospheric $\mathrm{CO}_{2}$ and $\mathrm{O}_{2}$ columns (Eq. 1) minimizes systematic and correlated errors, e.g. errors in the solar zenith angle, pressure errors, and influences of the instrumental line shape present in both retrieved $\mathrm{CO}_{2}$ and $\mathrm{O}_{2}$ columns (Washenfelder et al., 2006; Wunch et al., 2011).

The $\mathrm{CO}_{2}$ column is retrieved in two windows centered at $6220 \mathrm{~cm}^{-1}$ (window width $=80 \mathrm{~cm}^{-1}$ ) and $6339.5 \mathrm{~cm}^{-1}$ 


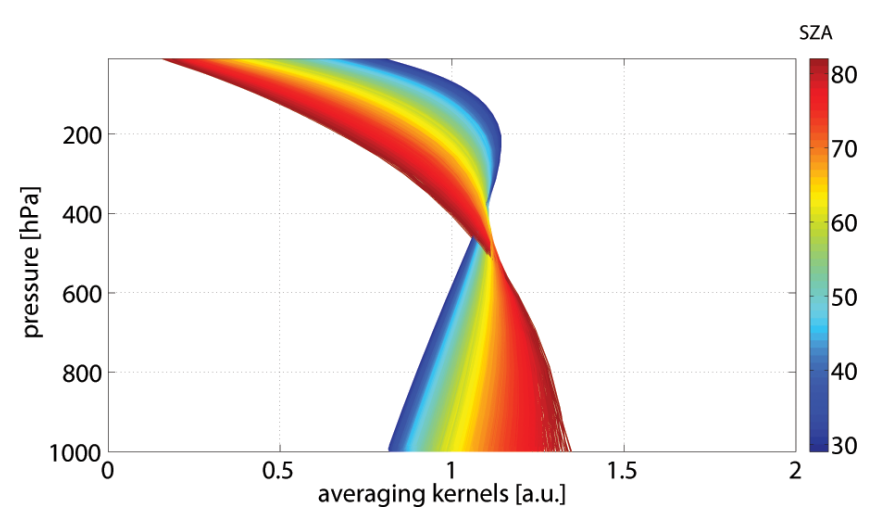

Fig. 3. $\mathrm{CO}_{2}$ averaging kernels for the presented Białystok FTS measurements, color coded for different solar zenith angles (SZA). The averaging kernels have no distinct maximum and are constant to first approximation within the troposphere and vary primarily due to different solar zenith angles.

(window width $=85 \mathrm{~cm}^{-1}$ ). The RMS-error weighted mean is used to calculate $\mathrm{X}_{\mathrm{CO}_{2}}$. Column $\mathrm{O}_{2}$ is retrieved from the electronic band centered at $7882 \mathrm{~cm}^{-1}$ (window width $=240.00 \mathrm{~cm}^{-1}$ ). The airmass dependence is corrected with an empirically derived relationship supplied with the software package and described in Wunch et al. (2011) and Deutscher et al. (2010). Data outside the range [0.20-0.22] for $\mathrm{O}_{2}$, as well as outside the range [350-420 ppm] for $\mathrm{CO}_{2}$ are regarded as outliers in the TCCON standard retrieval and discarded.

The averaging kernel for the column retrieval is a vector representing the sensitivity of the retrieved total column to perturbations of the partial columns at the various atmospheric levels. Typical averaging kernels of the TCCON retrieval are shown in Fig. 3, color coded by solar zenith angle.

All main retrieval processing steps are outlined in Fig. 4. Further details about the TCCON retrieval, e.g. sensitivity tests, are found in Wunch et al. (2011). All presented measurement data were obtained with SLICE-IPP version 20100123, and the TCCON standard retrieval was performed with GFIT version 4.4.10.

The Białystok FTS instrument was calibrated to WMO standards during the IMECC campaign. The IMECC campaign was the first calibration campaign of six European FTS sites (Messerschmidt et al., 2011). The results of the IMECC campaign, as well as the results of all other calibration campaigns within TCCON, demonstrate that a single global calibration factor can be applied (Deutscher et al., 2010; Wunch et al., 2010; Washenfelder et al., 2006). The resulting single global calibration factor to WMO scale was applied to the data presented here.

The Białystok FTS data were systematically affected prior to 27 September 2009 by a periodic laser mis-sampling, described in Messerschmidt et al. (2010). Briefly, a periodic laser mis-sampling leads to artificial spectral lines, called

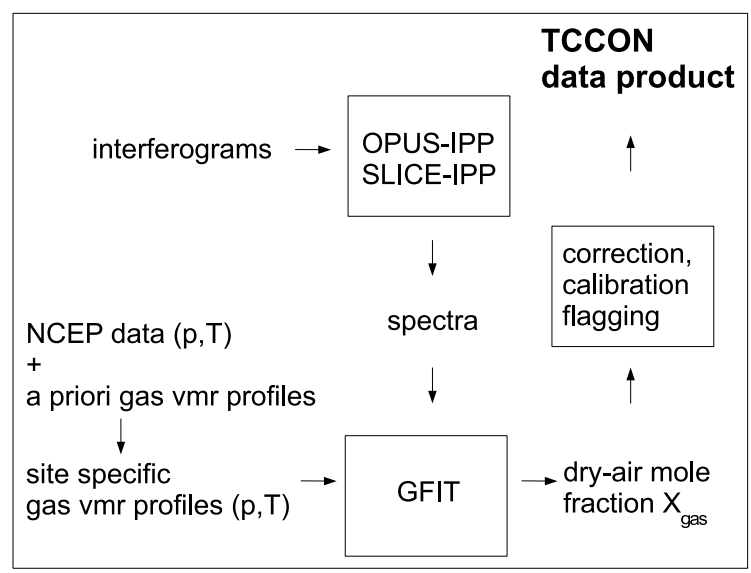

Fig. 4. The TCCON standard retrieval. The measured interferograms are transformed into spectra with the OPUS-IPP or SLICEIPP software. The initial vertical gas mole fraction profile, the a priori profile, is approximated with NCEP/NCAR analysis data for the measurement site and day. In GFIT this a priori profile, along with spectra e.g. of the HITRAN database (Rothman et al., 2009) and the modeled atmospheric data, is used to calculate a theoretical spectrum. This spectrum is then scaled to provide the best fit to the measured spectrum. After correction, calibration and data flagging, the TCCON product are column-averaged dry-air mole fractions $\mathrm{X}_{\text {gas }}$.

ghosts, which can interfere with the spectral range used for the gas retrieval. For a typical laser mis-sampling, the retrieved $\mathrm{X}_{\mathrm{CO}_{2}}$ is affected by about $1 \mathrm{ppm}$. Following Messerschmidt et al. (2010), the influence of the laser mis-sampling on the retrieved $\mathrm{X}_{\mathrm{CO}_{2}}$ has been quantified and the missampling was aligned to minimize the influence of the ghosts. The Bialystok FTS was aligned at 27 September 2009. Prior this date the $\mathrm{X}_{\mathrm{CO}_{2}}$ was changed by $0.96 \mathrm{ppm}$ through the influence of the ghosts. After the alignment, the ghosts have a negligible impact of less than $0.08 \mathrm{ppm}$ on the $\mathrm{X}_{\mathrm{CO}_{2}}$.

The Messerschmidt et al. (2010) correction scheme does not predict the sign of the ghosts, which means that it is ambiguous as to whether the ghosts lead to an over- or an underestimation of the retrieved $\mathrm{X}_{\mathrm{CO}_{2}}$. For the Bialystok FTS, the sign was determined empirically, by assessing the agreement between the $\mathrm{X}_{\mathrm{CO}_{2}}$ time series pre- and post-ghost minimization (before and after 27 September 2009). With the assumption that no physical reasons for a sudden $\sim 2 \mathrm{ppm}$ step exist at 27 September 2009, the presented FTS data are corrected by adding $0.96 \mathrm{ppm}$ to the data prior 27 September 2009. This approach was unambiguous due to the large magnitude of the ghosts $(0.96 \mathrm{ppm})$.

\section{FTS measurements in comparison with the collocated tall tower measurements}

With a top height of more than $300 \mathrm{~m}$, the Białystok tall tower is one of the tallest in Europe. The gas measurements at the 


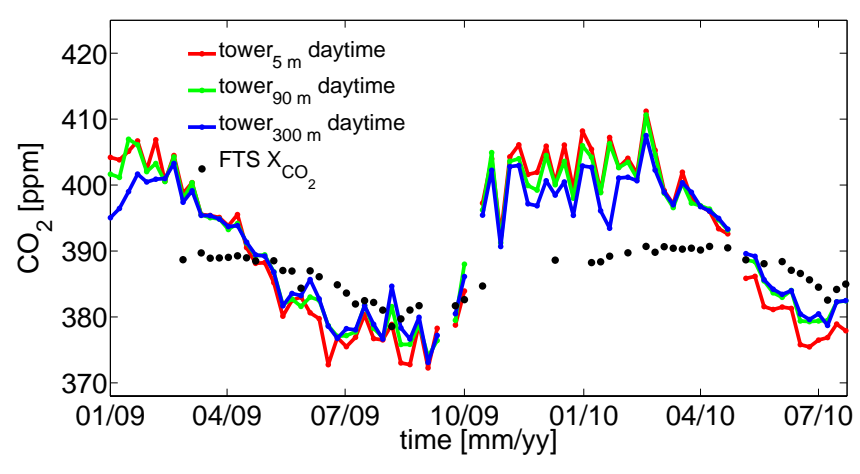

Fig. 5. The daytime $\mathrm{CO}_{2}$ time series for three tall tower levels $(5 \mathrm{~m}, 90 \mathrm{~m}, 300 \mathrm{~m})$ highlighting the seasonal cycle in comparison with the FTS measurements. All measurements are shown as weekly averages of daytime measurements between 12:00 p.m. and 03:00 p.m. LT. Gaps in the data records are due to instrumental problems.

tall tower are operated by the MPI-BGC (Jena, Germany). A variety of atmospheric trace gases have been sampled at five levels $(5 \mathrm{~m}, 30 \mathrm{~m}, 90 \mathrm{~m}, 180 \mathrm{~m}, 300 \mathrm{~m})$ quasi-continuously since 2005. $\mathrm{CO}_{2}$ volume mixing ratios are measured with a LI-COR LI-7000 NDIR gas analyzer. Further instruments are an Oxzilla FC-2 fuel cell analyzer for $\mathrm{O}_{2}$ and an Agilent 6890 gas chromatograph for $\mathrm{CH}_{4}, \mathrm{CO}, \mathrm{N}_{2} \mathrm{O}$, and $\mathrm{SF}_{6}$, described in Popa et al. (2010).

Daytime $\mathrm{CO}_{2}$ time series for three tall tower levels $(5 \mathrm{~m}$, $90 \mathrm{~m}, 300 \mathrm{~m}$ ) are shown in Fig. 5, and nocturnal $\mathrm{CO}_{2}$ time series in Fig. 6. All measurements are shown as weekly means of daytime and nocturnal averages for measurements between 12:00 p.m. and 03:00 p.m., and 00:00 a.m. and 05:00 a.m. LT, respectively. Gaps in the data record are due to instrumental failures, e.g. air conditioning problems. The figures show the effects of the covariance between surface fluxes and atmospheric $\mathrm{CO}_{2}$ transport:

On a diurnal scale, photosynthesis starts after sunrise, leading to $\mathrm{CO}_{2}$ uptake by the biosphere. Simultaneously, surface warming leads to reduced static stability, breakdown of the nocturnal boundary layer, vertical mixing of near-surface $\mathrm{CO}_{2}$ and thus deepening of the planetary boundary layer (PBL). Since the PBL is well mixed (including air from the former nocturnal boundary layer), the decrease in $\mathrm{CO}_{2}$ concentration at the surface (from uptake by the biosphere) is attenuated. Conversely, after sunset the Earth surface cools leading to the development of a stable (nocturnal) boundary layer where $\mathrm{CO}_{2}$ concentration are enhanced due to plant respiration. These effects can be seen in Figs. 5 and 6. Midafternoon $\mathrm{CO}_{2}$ is at least approximately uniformly mixed throughout the lower $300 \mathrm{~m}$ of the atmosphere in all seasons and the daytime $\mathrm{CO}_{2}$ concentrations are similar at all three levels throughout the year (Fig. 5). In contrast, the nocturnal $\mathrm{CO}_{2}$ concentrations are different for all tall tower heights, and always highest near the surface because of the $\mathrm{CO}_{2}$ accumulation in the nocturnal boundary layer (Fig. 6). The

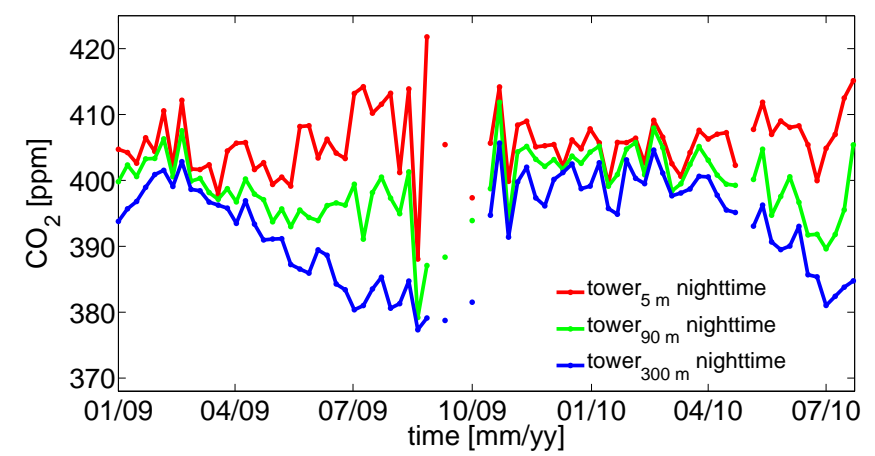

Fig. 6. The nocturnal $\mathrm{CO}_{2}$ time series for three tall tower levels $(5 \mathrm{~m}, 90 \mathrm{~m}, 300 \mathrm{~m})$ highlighting the seasonal cycle. The measurements are shown as weekly averages of nighttime measurements between 00:00 a.m. and 05:00 a.m. LT. Gaps in the in situ data record are due to instrumental problems.

daily gradients between daytime and nocturnal $\mathrm{CO}_{2}$ concentrations are the highest in summer, because the plant respiration is strongest at this time.

On a seasonal scale, the $\mathrm{CO}_{2}$ concentration is attenuated by long-range atmospheric transport or advection of air masses that are not influenced by terrestrial biosphere fluxes. In summer, strong convections lead to a deep PBL mixing, a dilution of the photosynthesis signal by $\mathrm{CO}_{2}$ transport into the free troposphere and by advection. In winter, weak convections entail shallow PBL mixing, an accumulation of the respiration signal near the surface and elevated $\mathrm{CO}_{2}$ concentration in the lower troposphere. This effect explains the stable layering even for day times in winter.

Overall, the $\mathrm{CO}_{2}$ exchange at the surface leads to the largest daytime seasonal cycle at the lowest tall tower level, but is attenuated due to the transport to the free troposphere.

The FTS time series shows the seasonality of biospheric uptake and respiration, but muted compared to the tall tower measurements. This is due to the fact that total column measurements are dominated by global flux distributions and local and regional fluxes have only a minor impact (KeppelAleks et al., 2012). The differences between the FTS data and the tall tower data are smallest in summer, as the photosynthesis signal is well mixed through transportation into the free troposphere. $\mathrm{CO}_{2}$ concentrations measured at the tall tower are representative of the tropospheric $\mathrm{CO}_{2}$ concentration and therefore vary in a similar way to the total column measurements. In contrast, the difference is large in winter, as the respiration signal is accumulated at the surface.

\section{FTS measurements in comparison with the $\mathrm{Jena}^{\mathrm{CO}_{2}}$ inversion model}

The Jena $\mathrm{CO}_{2}$ inversion (JC) estimates surface $\mathrm{CO}_{2}$ fluxes based on atmospheric $\mathrm{CO}_{2}$ concentration measurements provided by various institutions (Rödenbeck, 2005). The 
atmospheric transport is calculated by the global off-line atmospheric transport model TM3 (Heimann and Koerner, 2003). It has a spatial resolution of approximately $4^{\circ} \times 5^{\circ}$ (latitude $\times$ longitude) with 19 vertical levels and is driven by meteorological fields derived from NCEP reanalysis data.

Here, the special run ana96_v3.3, designed to provide three dimensional atmospheric tracer fields, is used. Bialystok data were not used in the flux inversion, which was the basis for the analyzed fields. A priori distributions for fossil fuel emissions are derived from the EDGAR v4.0 emission database (Olivier and Berdowski, 2001). The Biome-BGC model is used as land biosphere net ecosystem exchange (NEE) model (White et al., 2000; Churkina and Trusilova, 2002). To estimate the ocean $\mathrm{CO}_{2}$ uptake, an inversion based on ocean carbon data (Gloor et al., 2003; Mikaloff Fletcher et al., 2007) with small scale spatial and seasonal patterns, given by Takahashi et al. (2002), is used. The basic approach is as described in Rödenbeck et al. (2003), with updates described in Rödenbeck (2005) and Rödenbeck et al. (2006). The atmospheric fields and further information are available at http://www.bgc-jena.mpg.de/ christian.roedenbeck/ download-CO2-3D/.

\subsection{Data analysis}

In order to compare the Jena $\mathrm{CO}_{2}$ inversion profile data with the FTS measurements, they have to be integrated to columnaveraged $\mathrm{CO}_{2}$ dry-air mole fractions. We do this by applying the FTS averaging kernels and a priori profiles to the model, employing the method developed by Rodgers and Connor (2003). This approach is used in the modification described by Wunch et al. (2010).

Only model values for which contemporary FTS measurements exist were considered. FTS measurements can only be acquired when the sun is not obscured by clouds, therefore the comparison is restricted to these conditions. For each FTS measurement, the nearest model result within one hour was smoothed with the averaging kernel of the FTS measurement. The smoothed model profile data were integrated vertically to column-averaged $\mathrm{CO}_{2}$ dry-air mole fractions. The GFIT a priori $\mathrm{H}_{2} \mathrm{O}$ profile, which is based on NCEP reanalysis data, is used for the integration.

The bottom panel of Fig. 7 shows the daily averages of the integrated model values compared to the daily averages of the FTS $\mathrm{X}_{\mathrm{CO}_{2}}$ time series. The time series exhibits several gaps due to bad weather conditions, instrumental problems, e.g. solar tracker failures, or internal laser breakdown.

In the upper panel, the difference (FTS minus model) of the daily averages is shown. The mean difference of $-1.2 \mathrm{ppm} \pm 0.9 \mathrm{ppm}(1 \sigma)$ is given as a thin black line. The differences between the FTS data and the model simulation are rather small, but vary with time. This indicates that to first order, the Jena $\mathrm{CO}_{2}$ inversion captures the seasonal amplitude and phase of the column measurements well. This is challenging because it is difficult to model the biospheric
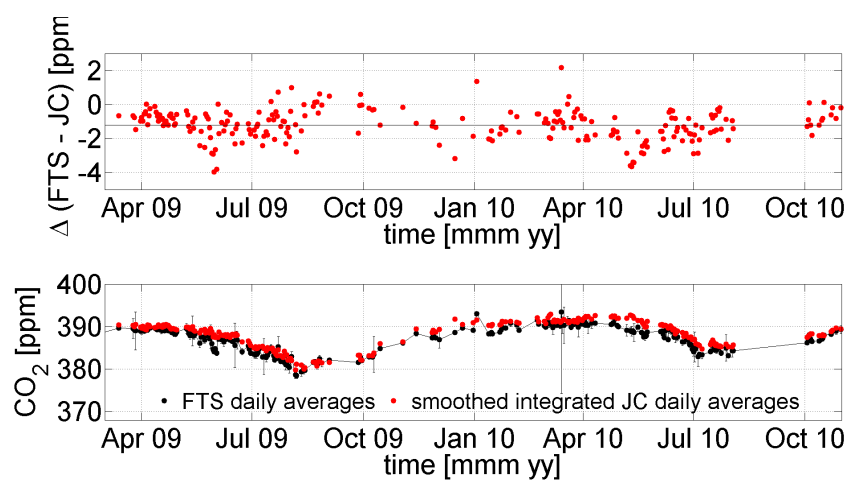

Fig. 7. Upper panel: the difference between the Białystok FTS daily averages and the corresponding integrated model data. The black line indicates the mean difference. Bottom panel: the daily averages of the integrated model data of the Jena $\mathrm{CO}_{2}$ inversion in comparison with the daily averages of the FTS time series ( $1 \sigma$ standard deviation as error estimation).

uptake in Europe due to the heterogeneous distribution of a large variety of ecosystems in a comparatively small land area. The differences are, however, time-dependent and will be further investigated in a future multi-year comparison. In this first investigation, the differences are analyzed with onsite in situ data.

\subsection{The Jena $\mathrm{CO}_{2}$ inversion model in comparison with the tall tower measurements}

The tall tower measurements are compared with the model levels corresponding to the tall tower measurement heights. The lowest tall tower level at $5 \mathrm{~m}$ is best to compare with the first model level that reaches from the ground up to around $80 \mathrm{~m}$. The $\mathrm{CO}_{2}$ time series at $90 \mathrm{~m}$ is best simulated with the second model level approximately between $80 \mathrm{~m}$ and $210 \mathrm{~m}$ and the tall tower height of $300 \mathrm{~m}$ is best captured with the third model level covering around $210 \mathrm{~m}$ up to $380 \mathrm{~m}$. The $\mathrm{CO}_{2}$ time series for the three tall tower heights are depicted in comparison with the model level results in Fig. 8. All data are given as weekly averages of daytime measurements between 12:00 p.m. and 03:00 p.m.. The mean differences between the model data and the tall tower measurements for the three level heights are given in Table 1 . The Jena $\mathrm{CO}_{2}$ inversion captures the uniformly mixed $\mathrm{CO}_{2}$ at all three levels throughout the year and simulates the stable layering at daytimes in winter as well.

The nocturnal time series for the three levels are shown in Fig. 9 and the mean nocturnal differences between the model data and the tall tower measurements are also given in Table 1. All data are given as weekly averages of nighttime measurements between 00:00 a.m. and 05:00 a.m. The nocturnal seasonal cycle at $300 \mathrm{~m}$ is captured, whereas the model does not simulate the nocturnal $\mathrm{CO}_{2}$ accumulation, especially in the summer (Fig. 9). The simulations at the three 


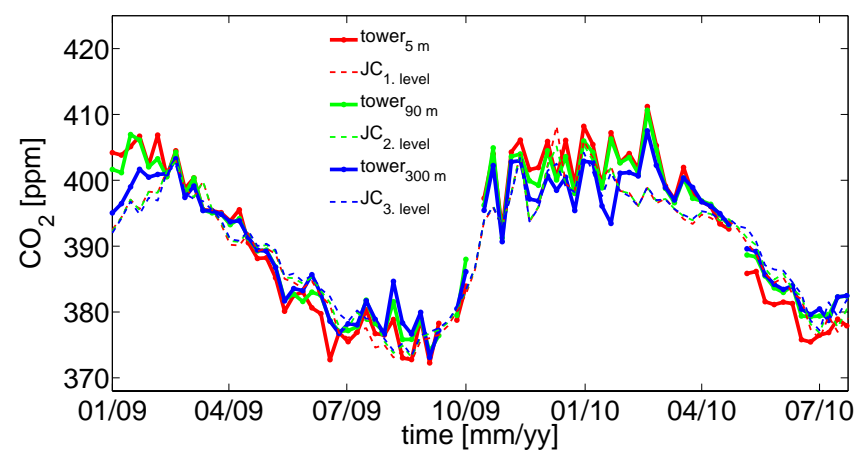

Fig. 8. The Jena $\mathrm{CO}_{2}$ inversion at levels corresponding to the tall tower levels in comparison with the tall tower data $(5 \mathrm{~m}$, $90 \mathrm{~m}, 300 \mathrm{~m}$ ). Weekly averages of daytime measurements between 12:00 p.m. and 03:00 p.m. are compared. The Jena $\mathrm{CO}_{2}$ inversion captures the seasonal cycle at all three levels, but slightly underestimates the $\mathrm{CO}_{2}$ concentration at all levels. Mean differences for all levels are given in Table 1.

Table 1. Mean differences between model data and tall tower measurements.

\begin{tabular}{|c|c|c|}
\hline $\begin{array}{r}\text { altitude } \\
{[\mathrm{m}]}\end{array}$ & $\begin{array}{r}\Delta \mathrm{CO}_{2}(\mathrm{JC}-\text { tall tower }) \\
\text { daytime }\end{array}$ & $\begin{array}{r}\Delta \mathrm{CO}_{2}(\mathrm{JC}-\text { tall tower }) \\
\text { nighttime }\end{array}$ \\
\hline 5 & -1.5 & -9.1 \\
\hline 90 & -1.6 & -5.9 \\
\hline 300 & -0.7 & -1.3 \\
\hline
\end{tabular}

levels exhibit a similar seasonal cycle and only a slight and nearly constant inversion throughout the year.

Figures 10 and 11 show the mean diurnal cycle at the tall tower level of $5 \mathrm{~m}$ for summer and winter in comparison to the model results. The model simulates a nearly constant diurnal cycle in summer and winter. The nocturnal $\mathrm{CO}_{2}$ accumulation in the summer due to plant respiration is not simulated in the model.

The false representation of the modulation of the nocturnal $\mathrm{CO}_{2}$ accumulation could be due to an imperfect vertical mixing, e.g. the stable boundary layer during the night is not well represented or due to imperfect fluxes. Imperfect fluxes can result from false partitioning of the respiration and the gross primary production (GPP), but a more or less reasonable net ecosystem exchange (NEE) as constrained by the inversion. If the vertical mixing is too strong, but the fluxes are correct, the modeled mixing ratios would be increased at $300 \mathrm{~m}$, because the nocturnal accumulated $\mathrm{CO}_{2}$ would have been transported to higher layers. If the vertical mixing was not strong enough, the resulting vertical $\mathrm{CO}_{2}$ gradient would be too high. The good representation of the nocturnal seasonal cycle at $300 \mathrm{~m}$ and the low vertical $\mathrm{CO}_{2}$ gradient suggests a false partitioning of the NEE.

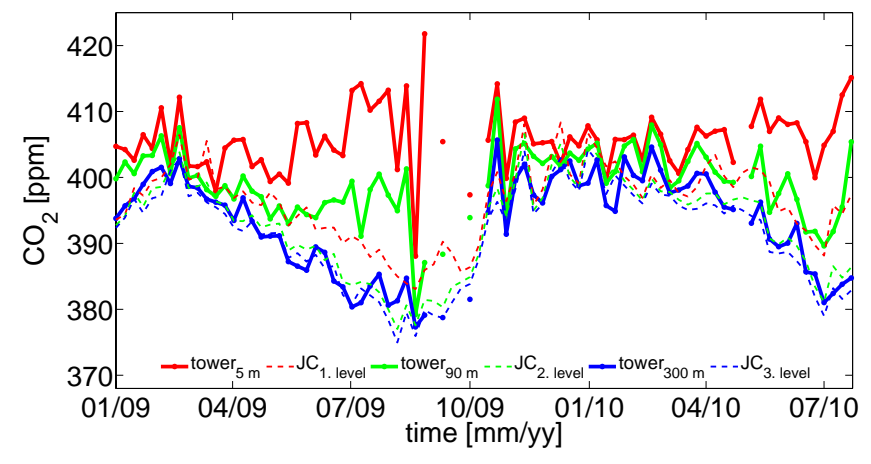

Fig. 9. The Jena $\mathrm{CO}_{2}$ inversion at levels corresponding to the tall tower levels in comparison with the tall tower data $(5 \mathrm{~m}$, $90 \mathrm{~m}, 300 \mathrm{~m}$ ). Weekly averages of nighttime measurements between 00:00 a.m. and 05:00 a.m. are compared. The model captures the seasonal cycle at the upper level, but fails to simulate the nighttime $\mathrm{CO}_{2}$ accumulation seen especially in summer at $5 \mathrm{~m}$ and $90 \mathrm{~m}$.

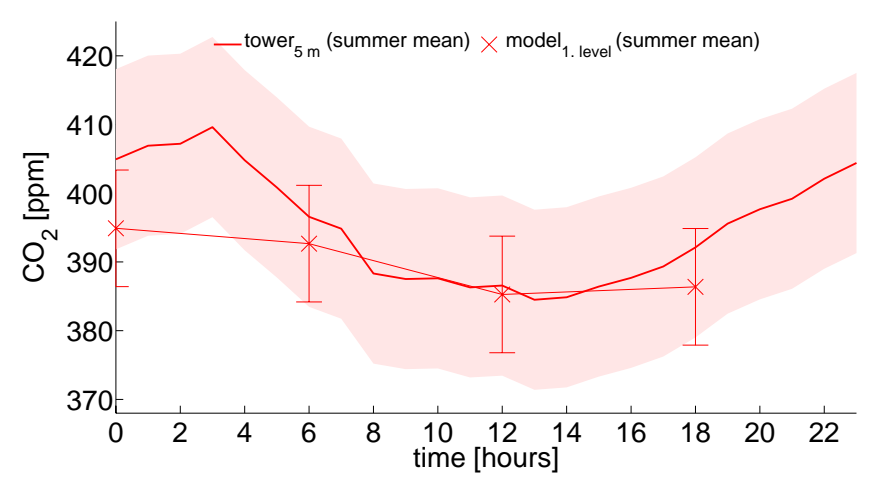

Fig. 10. Mean diurnal cycle for the summer. The red curve shows the mean diurnal cycle at the tall tower level of $5 \mathrm{~m}(1 \sigma$ standard deviation shown shaded in red). The mean model outputs are given as red stars ( $1 \sigma$ standard deviation as error estimation). The model does not simulate the nocturnal $\mathrm{CO}_{2}$ accumulation in the summer.

\subsection{The Jena $\mathrm{CO}_{2}$ inversion model in comparison with low aircraft measurements}

The model simulation in the upper PBL and lower free troposphere is investigated with low aircraft profiles taken on a regular basis near the Białystok site approximately every month. The quality of the aircraft data is ensured by comparison to independent $\mathrm{CO}_{2}$ mixing ratio measurements from an in situ analyzer, and analyzes of flask samples collected during the flights (Chen et al., 2012). A total of 12 low aircraft profiles were available for the analyzed time period and are listed in Table 2. The measurements were taken in spirals at an average distance of $9 \mathrm{~km}$ (between $2 \mathrm{~km}$ and $13 \mathrm{~km}$ ) from the Białystok site.

In order to compare the low aircraft profile measurements, the aircraft profiles and the model profiles are interpolated on the common pressure-grid used for the integration in Sect. 4.1. The low aircraft profiles are compared at pressure 
Table 2. Low aircraft overpasses available for the analyzed time period at the Białystok site. The date, the time difference to nearest available model output, the distance and altitude range are listed. The last column shows the difference between the integrated extended low aircraft profiles and the integrated most contemporary model result.

\begin{tabular}{lcccr}
\hline $\begin{array}{l}\text { time period } \\
\text { [dd-mmm HH:MM] }\end{array}$ & $\begin{array}{c}\Delta t(\mathrm{JC}-\text { in situ }) \\
{[\mathrm{HH}: \mathrm{MM}]}\end{array}$ & $\begin{array}{c}\text { dist. range } \\
{[\mathrm{km}]}\end{array}$ & $\begin{array}{c}\text { alt. range } \\
{[\mathrm{km}]}\end{array}$ & $\begin{array}{r}\Delta(\mathrm{JC}-\text { assembled JC }) \\
{[\mathrm{ppm}]}\end{array}$ \\
\hline 31 Mar 14:09-15:21 & $02: 09$ & $2.44-13.32$ & $0.09-2.47$ & 0.00 \\
8 Apr 08:48-10:06 & $02: 48$ & $1.74-12.28$ & $0.09-2.52$ & -0.44 \\
27 Apr 15:35-16:53 & $03: 35$ & $2.58-13.49$ & $0.09-2.53$ & 0.25 \\
15 May 14:45-15:51 & $08: 45$ & $1.24-13.07$ & $0.08-2.47$ & 0.41 \\
29 May 10:29-11:30 & $01: 30$ & $1.21-52.50$ & $0.12-2.54$ & 0.13 \\
15 Jun 11:44-12:56 & $00: 10$ & $0.92-14.04$ & $0.09-2.62$ & 0.68 \\
29 Jun 11:08-12:09 & $00: 51$ & $2.24-13.08$ & $0.11-2.67$ & 0.43 \\
7 Jul 10:29-11:42 & $01: 30$ & $2.54-13.15$ & $0.07-2.63$ & -0.05 \\
18 Jul 08:51-10:04 & $02: 51$ & $2.55-13.38$ & $0.11-2.65$ & 2.21 \\
10 Aug 13:10-14:18 & $16: 49$ & $2.15-17.59$ & $0.11-2.79$ & 1.09 \\
25 Aug 11:30-11:38 & $00: 30$ & $3.04-13.83$ & $0.10-0.34$ & -0.42 \\
27 Nov 11:13-11:49 & $00: 46$ & $2.64-13.00$ & $0.10-1.47$ & -0.36 \\
\hline
\end{tabular}

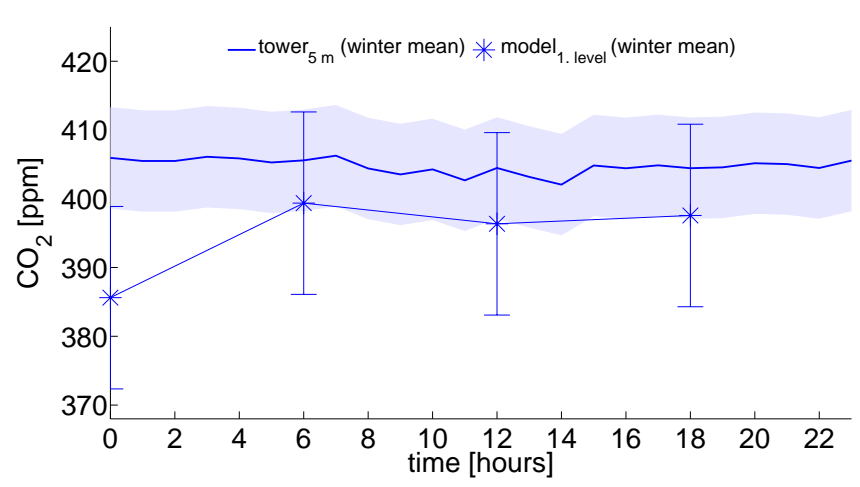

Fig. 11. Mean diurnal cycle for the winter. The blue curve shows the mean diurnal cycle at the tall tower level of $5 \mathrm{~m}(1 \sigma$ standard deviation shown shaded in blue). The mean model outputs are given as blue stars ( $1 \sigma$ standard deviation as error estimation). The model underestimates the $\mathrm{CO}_{2}$ concentration, especially in the night.

levels corresponding to the surface and altitudes of 1,2 , and $3 \mathrm{~km}$ to the most contemporary model profile. The time differences between the model profiles and the low aircraft profiles are listed in Table 2. In Fig. 12, the differences between the model and the aircraft profiles are shown color-coded for all model profiles for which low aircraft profiles within $2 \mathrm{~h}$ existed. $\mathrm{A} \mathrm{CO}_{2}$ overestimation by the model output leads to a positive difference, and vice versa. The thick black line indicates the mean difference for all profiles. On average the model underestimates the $\mathrm{CO}_{2}$ at the surface (up to $2.5 \mathrm{ppm}$ ), but with a high variability. At altitudes of $1 \mathrm{~km}$ and $2 \mathrm{~km}$ the model overestimates the $\mathrm{CO}_{2}$ (by up to $1 \mathrm{ppm}$ ), whereas at $3 \mathrm{~km}$ the $\mathrm{CO}_{2}$ is nearly captured on average. These findings correspond to the underestimation of the tall tower measurements (Table 1) and the overestimation of the FTS measurements by a mean difference of $1.2 \mathrm{ppm} \pm 0.9 \mathrm{ppm}(1 \sigma)$ (Fig. 7).

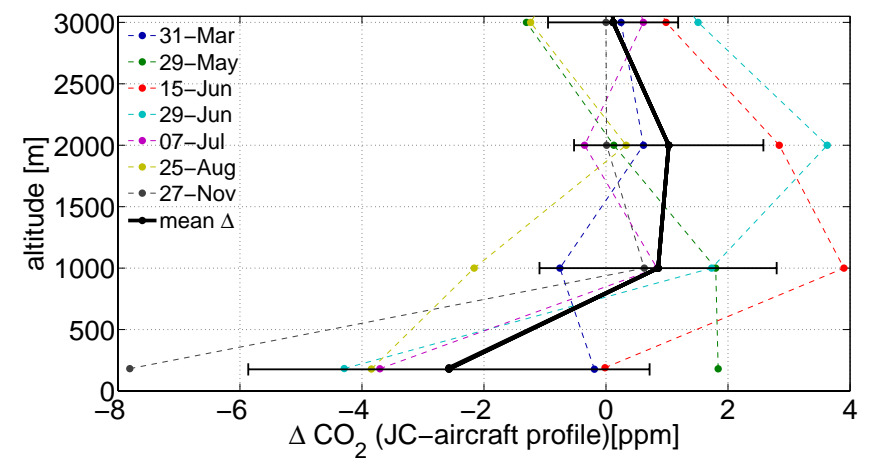

Fig. 12. Difference between the model profiles and contemporary low aircraft profiles on the common pressure-grid used for the integration in Sect. 4.1. For the analyzed time period overall 12 low aircraft profiles up to $2.8 \mathrm{~km}$ were conducted, of which 7 profiles were done within $2.15 \mathrm{~h}$ of an available model output. The mean of the differences is given with a black line. At the ground the Jena $\mathrm{CO}_{2}$ inversion underestimates the $\mathrm{CO}_{2}$ concentration on average (by up to $2.5 \mathrm{ppm}$ ) and overestimates it in 1 and $2 \mathrm{~km}$ (by up to $1 \mathrm{ppm}$ ).

To compare the total column averages directly, the aircraft profiles were extended above the aircraft ceiling by attaching the most contemporary model profile to the highest aircraft measurement. Afterwards, the extended profiles were integrated as described in Sect. 4.1. The differences between the integrated extended low aircraft profiles and the integrated most contemporary model profiles are listed in Table 2 . In Fig. 13, the scatter of the $\mathrm{CO}_{2}$ total column averages calculated with the extended aircraft profiles is shown in comparison to the original model data. Using the low aircraft profile measurements leads to a slightly better estimation of the $\mathrm{X}_{\mathrm{CO}_{2}}$ (correlation coefficient of 0.996). Calculated only for the overpass days, it reduces the difference of $1.06 \mathrm{ppm} \pm 0.35 \mathrm{ppm}$ between the Jena $\mathrm{CO}_{2}$ inversion and the FTS data to $1.00 \mathrm{ppm} \pm 0.26 \mathrm{ppm}$. 


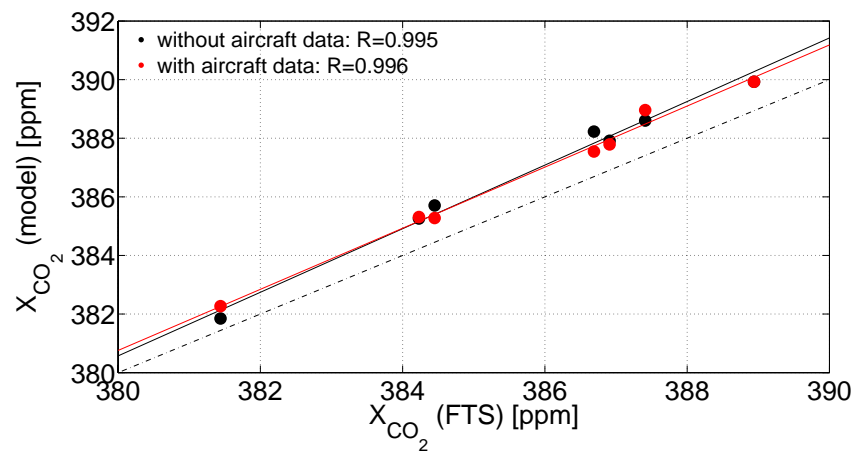

Fig. 13. Scatter plot of the $\mathrm{CO}_{2}$ total column averages calculated with the extended aircraft profiles in comparison to the original model data. Using the low-level aircraft profile measurements leads to a slightly better estimation of the $\mathrm{X}_{\mathrm{CO}_{2}}$.

\section{Conclusions}

The FTS $\mathrm{X}_{\mathrm{CO}_{2}}$ dataset presented here demonstrates the ability of the automated FTS system to continuously measure trace gas total columns in the near infrared. The FTS total $\mathrm{CO}_{2}$ column measurements show the expected muted seasonal cycle compared to the collocated tall tower $\mathrm{CO}_{2}$ measurements due to the fact that they are dominated by largescale $\mathrm{CO}_{2}$ variations and are less sensitive to local variations.

Evaluation of the Jena $\mathrm{CO}_{2}$ inversion model with the FTS data shows that the model is able to predict monthly variations, despite a time dependent mean overestimation of $1.2 \mathrm{ppm} \pm 0.9 \mathrm{ppm}(1 \sigma)$. This difference was further analyzed by using tall tower measurements and low aircraft profiles. The tall tower data indicate a false simulation of the nocturnal respiration, but a good estimation of the midafternoon $\mathrm{CO}_{2}$ concentration. The comparison to the low aircraft profiles points to an underestimation at the surface (by up to $2.5 \mathrm{ppm}$ ) and an overestimation in the upper PBL and free troposphere (by up to $1 \mathrm{ppm}$ ). The integrated model data using the low aircraft profiles show a slight improvement compared to the original model data. Both the comparison with the low aircraft profiles and the FTS data show a tendency to overestimate the $\mathrm{CO}_{2}$ in the troposphere. This is not in contradiction to the underestimation of the nocturnal respiration, because the nocturnal $\mathrm{CO}_{2}$ accumulation contributes only a small part of the total $\mathrm{CO}_{2}$ column abundance. For example an underestimation until $500 \mathrm{~m}(\approx 950 \mathrm{hPa})$ of $2 \mathrm{ppm}$ would lead in the total column $(80 \mathrm{~km} \approx 0.01 \mathrm{hPa})$ to a underestimation of around $0.12 \mathrm{ppm}(6.2 \% \times 2 \mathrm{ppm})$.

The multiple datasets available at the Białystok site give manifold information about the performance of model simulations. Total column measurements are a good validation resource for large-scale variations in atmospheric gas concentrations, because they are mainly dominated by synopticscale dynamics. In contrast the global in situ network gives a good database for local and regional flux estimations. A com- bination of total column measurements, serving as validation resource for large-scale $\mathrm{CO}_{2}$ estimations and in situ measurements, as optimization resource for local and regional fluxes, would improve $\mathrm{CO}_{2}$ sink estimations. It is not necessary that these measurement facilities are located at the same site, but the combination of a global total column measurement network, like TCCON, and a global in situ measurement network would improve the constraints of the carbon cycle by their complementary information. Multiple datasets at one site, like in Białystok are additionally suitable for regional studies.

\section{Appendix A}

\section{The automated FTS system}

The automation system is constructed for the temperate zone and successfully tested under temperatures from $-30^{\circ} \mathrm{C}$ to $40^{\circ} \mathrm{C}$. The minimization of maintenance, the safeness and stability of the system were key factors in the automation design. Long lasting and robust components as well as solid constructions and communication interfaces were chosen. The automation system offers multiple remote access, as well as the possibility of filing different trace gas measurement tasks for arbitrary time periods. The safeness of the data record is guaranteed by redundant data storage. A sophisticated logging system ensures that the system state is recorded at all times, and a basic automated error handling allows a minimum of local support.

In the following all used hardware components, the automation concept and the automation software are described in their basic function. All described hardware components are depicted in Fig. 2.

\section{A1 The hardware}

The automation system is housed in a modified $20^{\prime}$ standard shipping container. To minimize the possibility of deformation, parts of the roof were reinforced for the installation of the hatch and the solar tracker. Furthermore the container was insulated for operation in mid-latitudes, supplied with a basic electrical installation and equipped with an air condition to assure internal temperature stability. The voltage supply is protected by an Uninterruptible Power Supply (UPS). All subsystems communicate via an internal network and the system is connected to the Internet via multiple paths.

\section{A1.1 Main PLC}

A Programmable Logic Controller (PLC) (the "Main PLC") acts as the central unit responsible for safeguarding the system. In the case of a critical system status, the Main PLC brings the system in a save system state (e.g. hatch cover will be closed during rain or devices will be switched off). Beside this primary task, the Main PLC accumulates the data 
of the sensor system (weather station and room climate sensors), switches the power supply for central devices in the automation system (air conditioning, hatch system and all parts of the measurement system) and communicates in the daily routine with the Master PC (described in Sect. A1.2).

\section{A1.2 Master PC}

The Master PC is the host of the automation software and controls the actual measurement tasks. Based on the supplied information of the Main PLC and its own internal analyses, the Master PC controls the measurement system that encompasses the FTS instrument, the solar tracker and the data storage system.

\section{A1.3 Hatch system}

The main function of the hatch system is the protection of the solar tracker from dirt and damage. The hatch system encompasses the hatch cover, the hatch control cabinet and the compressed air supply (compressor, dryer, condensation drain, pressure vessel). The hatch cover is driven by pneumatic cylinders, which control opening and closing of the hatch. When the weather conditions allow this and the system shall perform measurements, seals in the opening of the hatch cover are vented and the hatch cover opens. When opened, the solar tracker can point at the sun and measurements can be carried out. When no solar measurements should be done, e.g. in the night or when the weather conditions do not allow to vent the seals, e.g. during rain or high wind speeds, the hatch is hermetically closed by pressurizing the seals. The hatch is closed, but the seals are not pressurized, when the weather conditions are not good enough (not sunny), but are uncritical (no rain, low wind speed). The main controls of the pneumatic system and the hatch PLC are mounted in the hatch control cabinet. The hatch PLC coordinates all actions of the hatch but is in turn controlled by the Main PLC. This means if the Main PLC requests e.g. the closing of the hatch, the hatch PLC will not interfere. Below the hatch a thermal screen is installed to prevent condensation on the solar tracker mirrors.

\section{A1.4 Solar tracker}

The solar tracker was built in the workshop of the University of Bremen. In principle the solar tracker consists of two mirrors mounted on a metal frame. The whole metal frame and one solar mirror are movable by rotation stages. For the positioning of the solar tracker mirrors, a commercially available motion controller was used (Fig. A1).

\section{A1.5 Fourier Transform Infrared Spectrometer (FTS)}

The measurement instrument is a Bruker IFS 125/HR Fourier Transform Infrared Spectrometer. It is optimized to measure gases such as $\mathrm{CO}_{2}, \mathrm{CH}_{4}, \mathrm{CO}, \mathrm{N}_{2} \mathrm{O}, \mathrm{H}_{2} \mathrm{O}, \mathrm{HDO}, \mathrm{O}_{2}$,

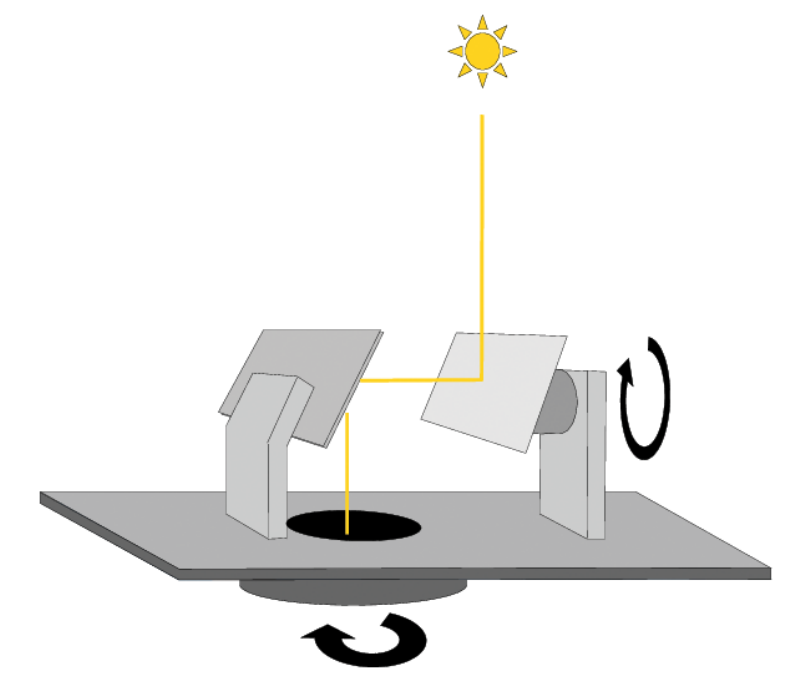

Fig. A1. The solar tracker, built in the workshop of the University of Bremen. In principle the solar tracker consists of two mirrors mounted on a metal frame. The whole metal frame and one solar mirror are movable with rotation stages. For the positioning of the solar tracker mirrors a motion controller is used. The calculation of the positioning is realized in the automation software (Sect. A3).

HF in the near infrared solar region. The maximum resolution is $0.0035 \mathrm{~cm}^{-1}$, and was chosen to allow an upgrade for MIR measurements in the future. A silicon ( $\mathrm{Si}$ ) diode detector, which is sensitive between $11000-15000 \mathrm{~cm}^{-1}$ and an Indium-Gallium-Arsenide (InGaAs) diode, which is sensitive within $3800-11000 \mathrm{~cm}^{-1}$ are installed. Using a dual channel measurement mode the spectral range from $3800 \mathrm{~cm}^{-1}$ up to $15000 \mathrm{~cm}^{-1}$ can be measured simultaneously within minutes. A Calcium-Fluoride $\left(\mathrm{CaF}_{2}\right)$ beam splitter is used. A hydrogen chloride $(\mathrm{HCl})$ cell is permanently mounted in the source compartment of the instrument, allowing the Instrumental Line Shape to be monitored monthly with tungsten lamp measurements (Hase et al., 1999). The measurements are conducted under vacuum to ensure stable, clean and dry conditions within the system. Therefore the system is equipped with an oil-free scroll pump (Varian TriSrcoll300) that evacuates the system over night.

The FTS instrument at Białystok is part of the TCCON and the measurement parameters are adapted for this purpose. Spectra are acquired with $0.014 \mathrm{~cm}^{-1}$ resolution, an aperture of $1 \mathrm{~mm}$ diameter and a scanner velocity of $10 \mathrm{kHz}$. The electronic low pass filter is set to $10 \mathrm{kHz}$ (corresponding to $15798 \mathrm{~cm}^{-1}$ ). The high folding limit for the Fast Fourier Transformation is set to $15798 \mathrm{~cm}^{-1}$. Two individual scans, one forward and one backward, are carried out per measurement. 


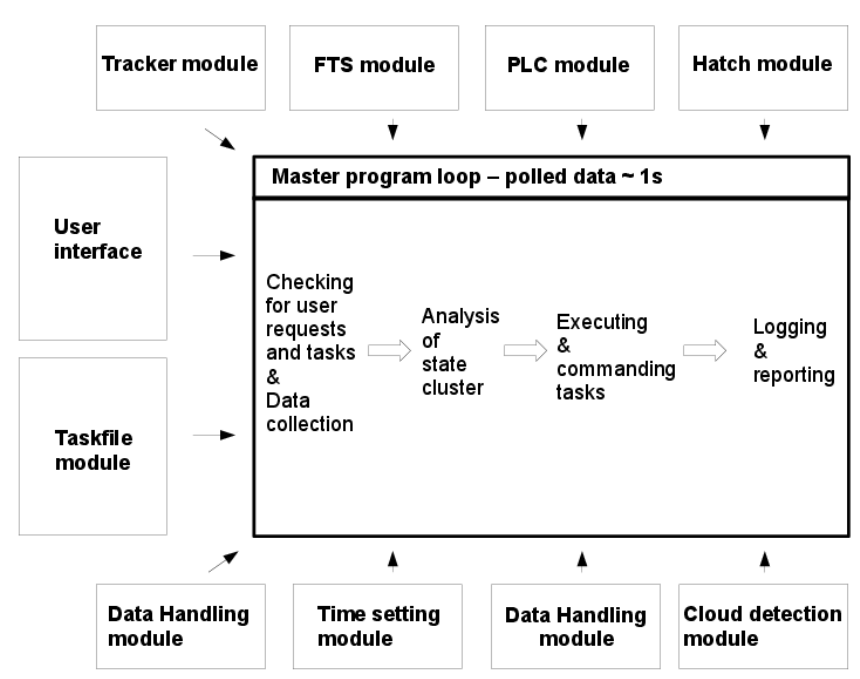

Fig. A2. Schematic of the interacting modules within the automation software. The Master Program collects all information of the submodules, grouped around the Master program. The Master program itself is set up in a loop process. It checks for local or remote user requests, collects the provided information of the submodules and analyzes these information. By commanding tasks to the subsystems, it executes subsequent actions. At the end of one loop, it logs all information as the state of the automation system.

\section{A1.6 Data storage}

During a measurement, the data are stored on a network attached storage (NAS). Each night, the FTS data are copied onto two tapes with a backup software.

Once a month, one tape is sent to the IUP, while the other tape remains in the container as a data backup. At the IUP, the data are read out and stored on a data storage system. Because of the high amount of data (Gbytes), it is not possible to send the data to the IUP via Internet.

\section{A1.7 Sensor system}

The automation system is equipped with several sensors to detect the weather conditions and to monitor the room climate. The weather station consists of sensors for pressure, temperature, humidity, wind speed, rain, and direct solar radiation. The room climate is recorded with temperature sensors and one humidity sensor. The specifications are found in Table A2.

\section{A2 The automation concept}

The automation system consists of the introduced subsystems: the Main PLC, the Master PC, the hatch system, the measurement system (solar tracker, FTS instrument and data storage system), and the sensor system. Three of these subsystems are the main controlling units: the Main PLC, the Hatch PLC, and the Master PC. Apart from automated activ-
Table A1. Matrix: the matrix has as columns the states of the subsystems and as rows actions, which follow from a certain system state. If the states of the subsystems (respectively the columns in the matrix) fit a wanted action (respectively a row in the matrix), the action will be communicated by the Master program and executed ( 0 : false, 1 : true, -1 : unimportant).

\begin{tabular}{lrrr}
\hline & Sunny Weather & FTS: No Error & Hatch: Open \\
\hline Measure & 1 & 1 & 1 \\
Error message & -1 & 0 & -1 \\
Close hatch & 0 & -1 & 1 \\
\hline
\end{tabular}

ities done by these controlling units, the automation system can be fully controlled by a local or remote operator.

The automation system has two operational states: run mode and sleep mode. The run mode is the normal operational state of the automation system. All subsystem are switch on and the system is able to measure fully automatically in case of good weather conditions. The sleep mode is the system state, in which all major subsystems are switch off. This state is designed in case of major instrumental failures. For example if the FTS instrument does not work, the hatch does not need to be opened and can be switched off. A transition between these states as well as the initialization and the reset of the automation system can be either triggered by the user (direct command input by a local/remote operator) or automatically executed.

The system can be controlled locally via the Main PLC control cabinet, the hatch control cabinet and the front panel of the automation software on the Master PC. Several LEDs and a LCD display, located at the front panel of the Main PLC control cabinet, indicate the state of the automation system and ongoing actions.

The standard access for the remote control is via Virtual Network Computing (VNC) (for error handling, debugging, remote control of the automation software) and ssh (for uploading updates, filing measurement tasks) to the Master PC. The connection to the Internet from the automated system is minimized for security reasons. Standard tasks using Internet connectivity are time setting, and sending of error emails in the case of instrumental failures and sending of the data storage status. Additional independent remote access is necessary, e.g. if the Internet connection is affected by an error, therefore a GSM modem was installed, via which basic functions are executable and information are provided via text messages.

\section{A3 The automation software}

The automation software integrates all instruments and decision-making devices into one automated system. The programming was divided into several subsystems: the PLCs are closed subsystems that were programmed with the software TwinCat, provided by Beckhoff Automation GmbH. 
Table A2. The weather station specifications.

\begin{tabular}{|c|c|c|c|c|}
\hline sensor & model & range & precision & remarks \\
\hline pressure & PTB220 Vaisala & $500-1100 \mathrm{hPa}$ & $0.1 \mathrm{hPa}$ & $\begin{array}{l}\text { calibrated with reference } \\
\text { sensor at least once a year }\end{array}$ \\
\hline temperature & $\begin{array}{l}\text { Hygro- } \\
\text { Thermogeber } \\
\text { Compact } \\
\text { 1.1005.54.241 } \\
\text { Thies Clima }\end{array}$ & $-30-+70^{\circ} \mathrm{C}$ & $\pm 0.3{ }^{\circ} \mathrm{C}$ & \\
\hline humidity & & $0-100 \%$ & $\pm 2 \%$ & \\
\hline wind speed & $\begin{array}{l}\text { Windgeber- } \\
\text { Compact } \\
\text { 4.3519.05.141 } \\
\text { Thies Clima }\end{array}$ & $0.5-50 \mathrm{~ms}^{-1}$ & $\begin{array}{l} \pm 0.5 \mathrm{~ms}^{-1}( \pm 3 \% \\
\text { of measurand })\end{array}$ & internal heater \\
\hline rain & $\begin{array}{l}\text { Niederschlags- } \\
\text { waechter } \\
5.4103 .10 .000 \\
\text { Thies Clima }\end{array}$ & yes/no & $\begin{array}{l}\text { rain detection condi- } \\
\text { tions are manually } \\
\text { adjustable }\end{array}$ & optical sensor \\
\hline \multirow[t]{3}{*}{ sun } & $\begin{array}{l}\text { CSD3 } \\
\text { Kipp\&Zonen }\end{array}$ & $0-1 \mathrm{~V}$ & $\begin{array}{l}1 \mathrm{mVWm}^{-2} \pm 33 \% \\
\text { at } 120 \mathrm{Wm}^{-2}\end{array}$ & direct solar radiation \\
\hline & & yes/no & & $\begin{array}{l}\text { sun duration } \\
\text { (threshold } 120 \mathrm{Wm}^{-2} \text { ) }\end{array}$ \\
\hline & \multicolumn{4}{|c|}{$\begin{array}{l}\text { to prevent condensation and snow/ice cover: } \\
\text { 1. heat level }(1 \mathrm{~W}, 12 \mathrm{~V}) \text { controlled by the Thies junction box } \\
\text { 2. heat level }(10 \mathrm{~W}, 12 \mathrm{~V}) \text { switched by the Main PLC }\left(T<5^{\circ} \mathrm{C}\right)\end{array}$} \\
\hline $\begin{array}{l}\text { room temperature } \\
\text { and humidity }\end{array}$ & \multicolumn{4}{|c|}{$\begin{array}{l}4 \times \text { PT100 distributed within the container } \\
(1 \times \text { rack, } 2 \times \text { FTS }, 1 \times \text { roof penetration })\end{array}$} \\
\hline
\end{tabular}

The GSM modem was programmed with the software TILA, provided by Tixi.com GmbH. The automation of all other devices was programmed with LabView 8.5 from National Instruments, a dedicated visual programming language for automating measurement systems. The structure of the automation software is modular, and overall 800 submodules were written. The basic modules are pictured in Fig. A2, and their main functions are explained in the following section.

\section{A3.1 Master program}

The Master program is the central unit of the automation software. It parameterizes the automation system, communicates with all devices, especially with the Main PLC and the measurement system, and is responsible for operating the measurements. The Master program initializes measurements, commands the opening of the hatch and the tracking of the sun, requests the setting of FTS parameters and organizes the collection and storage of the measurement data. Additionally, it $\log$ s the system state at all times and provides an interface for local and remote operators. The Master program itself works in a loop, which covers the following subroutines
1. checking for local or remote user requests,

2. collecting all necessary information from the modules,

3. analyzing all provided information,

4. executing subsequent actions,

5. commanding tasks to the subsystems, and

6. logging the state of the system.

The main steps of the loop are indicated in Fig. A2. The time of the loop can be set according to the speed at which the modules provide their subsystem states. The main analyzing tool is realized in a simple matrix. The matrix has as columns the states of the subsystems and as rows actions, which follow from a certain system state. Table A1 gives a simplified example of the matrix. As columns three states are given "Sunny weather conditions", "FTS has no errors", "Hatch is open". As rows three actions are given: the action "Measure solar absorption measurements" is only executed if all states are true, indicated with " 1 ". An error message is send, if the state "FTS has no errors" is false (indicated by " 0 ") independently of the two other states (indicated by 
"-1"). The action "Close hatch" is executed in the case of no sunny weather conditions and if the hatch is open. Following this structure the action will be communicated by the Master program and executed, if the states of the subsystems (respectively the columns in the matrix) fit a wanted action (respectively a row in the matrix). If there is no match in the matrix, no action will be executed. If required this matrix can be easily modified and adapted to specific needs in the system behavior just by editing the matrix in a spreadsheet.

All necessary communication with the subsystems and the executions of the actions take place in specialized software modules, which will be introduced in the following sections.

\section{A3.2 FTS Module}

The FTS Module controls the communication between the Master program and the FTS instrument. The IFS 125/HR instrument is equipped with an embedded web server (EWS). It is a standard web server/client base. The client, in our case the automation software, only sends requests to the web server and collects data. The EWS has two interfaces, a ftpand a http-interface. All measurement communication with the instrument is done via the http-interface. Even in the case when commands have to be send to the EWS, it is done by adding the appropriate query to the requested HTML page. The ftp-interface is exclusively used for firmware updates.

\section{A3.3 Taskfile Module}

In order to be able to prescribe tasks in arbitrary time periods, the automation software is equipped with the Taskfile module. Daily tasks can be stored in a simple text file. Thus, the vacuum pump can be switched on and off, measurements can be initialized, e.g. opening of the hatch, moving of the solar tracker, different measurement tasks can be filed and data can be written onto tapes.

\section{A3.4 Further Modules}

In additional modules, e.g. the sun tracking of the solar tracker is programmed (Tracker Module) and the theoretical direct solar radiation is calculated and compared to the input from the sun sensor (Cloud Detection Module). The underlying model for the calculation is a simplified clear sky model for direct and diffuse insolation on horizontal surfaces from Richard E. Bird, Solar Energy Research Institute, Colorado, USA (Bird and Hulstrom, 1981). In a further subroutine the data storage is realized (Data Handling Module). It checks for new files, and prepares the data for storage on tapes.

Acknowledgements. The Białystok FTS instrument was automated with fundings from the Senate of Bremen and within the framework of two European Union (EU) projects, IMECC (Infrastructure for Measurement of the European Carbon Cycle) and GEOmon (Global Earth Observation and Monitoring). The maintenance and logistical work is kindly provided by AeroMeteo Service in Białystok and the RAMCES team at LSCE (Gif-sur-Yvette, France) in Trainou. We acknowledge financial support by NASA's Program, grant number NNX11AG016, Constraining fluxes of carbon with total column measurements of $\mathrm{CO}_{2}$ and $\mathrm{CH}_{4}$.

Edited by: J. Brandt

\section{References}

Andrews, A. E., Boering, K. A., Daube, B. C., Wofsy, S. C., Loewenstein, M., Jost, H., Podolske, J. R., Webster, C. R., Herman, R. L., Scott, D. C., Flesch, G. J., Moyer, E. J., Elkins, J. W., Dutton, G. S., Hurst, D. F., Moore, F. L., Ray, E. A., Romashkin, P. A., and Strahan, S. E.: Mean ages of stratospheric air derived from in situ observations of $\mathrm{CO}_{2}, \mathrm{CH}_{4}$, and $\mathrm{N}_{2} \mathrm{O}$, J. Geophys. Res., 106, 32295-32314, doi:10.1029/2001JD000465, 2001.

Baker, D. F., Law, R. M., Gurney, K. R., Rayner, P., Peylin, P., Denning, A. S., Bousquet, P., Bruhwiler, L., Chen, Y.-H., Ciais, P., Fung, I. Y., Heimann, M., John, J., Maki, T., Maksyutov, S., Masarie, K., Prather, M., Pak, B., Taguchi, S., and Zhu, Z.: TransCom 3 inversion intercomparison: Impact of transport model errors on the interannual variability of regional $\mathrm{CO}_{2}$ fluxes, 1988-2003, Global Biogeochem. Cy., 20, GB1002, doi:10.1029/2004GB002439, 2006.

Bird, R. E. and Hulstrom, R. L.: Simplified Clear Sky Model for Direct and Diffuse Insolation on Horizontal Surfaces, Technical Report SERI/TR-642-761, Solar Energy Research Institute, 1981.

Bovensmann, H., Burrows, J. P., Buchwitz, M., Frerick, J., Noël, S., Rozanov, V. V., Chance, K. V., and Goede, A. P. H.: SCIAMACHY: Mission Objectives and Measurement Modes, Journal of the Atmospheric Sciences, 56, 127-150, doi:10.1175/15200469(1999)056<0127:SMOAMM>2.0.CO;2, 1999.

Chen, H., Winderlich, J., Gerbig, C., Katrynski, K., Jordan, A., and Heimann, M.: Validation of routine continuous airborne $\mathrm{CO}_{2}$ observations near the Bialystok Tall Tower, Atmos. Meas. Tech., 5, 873-889, doi:10.5194/amt-5-873-2012, 2012.

Churkina, G. and Trusilova, K.: A global version of the biome-bgc terrestrial ecosystem model, Tech. rep., Max Planck Institute for Biogeochemistry, Jena, 2002.

Crisp, D. C. E., Miller, P. L., and DeCola, P. L.: NASA Orbiting Carbon Observatory: measuring the column averaged carbon dioxide mole fraction from space, J. Appl. Remote Sens., 2, 023508, doi:10.1117/1.2898457, 2008.

Deutscher, N. M., Griffith, D. W. T., Bryant, G. W., Wennberg, P. O., Toon, G. C., Washenfelder, R. A., Keppel-Aleks, G., Wunch, D., Yavin, Y., Allen, N. T., Blavier, J.-F., Jiménez, R., Daube, B. C., Bright, A. V., Matross, D. M., Wofsy, S. C., and Park, S.: Total column $\mathrm{CO}_{2}$ measurements at Darwin, Australia - site description and calibration against in situ aircraft profiles, Atmos. Meas. Tech., 3, 947-958, doi:10.5194/amt-3-947-2010, 2010.

Geibel, M. C., Gerbig, C., and Feist, D. G.: A new fully automated FTIR system for total column measurements of greenhouse gases, Atmos. Meas. Tech., 3, 1363-1375, doi:10.5194/amt-31363-2010, 2010.

GLOBALVIEW-CO2: Cooperative Atmospheric Data Integration Project - Carbon Dioxide, NOAA-ESRL, Boulder, Colorado, cD-ROM, 2011. 
Gloor, M., Gruber, N., Sarmiento, J., Sabine, C. L., Feely, R. A., and Rödenbeck, C.: A first estimate of present and preindustrial air-sea $\mathrm{CO}_{2}$ flux patterns based on ocean interior carbon measurements and models, Geophys. Res. Lett., 30, 1010, doi:10.1029/2002GL015594, 2003.

Hase, F., Blumenstock, T., and Paton-Walsh, C.: Analysis of the Instrumental Line Shape of High-Resolution Fourier Transform IR Spectrometers with Gas Cell Measurements and New Retrieval Software, Appl. Optics, 38, 3417-3422, 1999.

Heimann, M. and Koerner, S.: The global atmospheric tracer model TM3, Technical Report 5, Max-Planck-Institut für Biogeochemie, 2003.

Keppel-Aleks, G., Toon, G. C., Wennberg, P. O., and Deutscher, N. M.: Reducing the impact of source brightness fluctuations on spectra obtained by Fourier-transform spectrometry, Appl. Optics, 46, 4774-4779, 2007.

Keppel-Aleks, G., Wennberg, P. O., Washenfelder, R. A., Wunch, D., Schneider, T., Toon, G. C., Andres, R. J., Blavier, J.-F., Connor, B., Davis, K. J., Desai, A. R., Messerschmidt, J., Notholt, J., Roehl, C. M., Sherlock, V., Stephens, B. B., Vay, S. A., and Wofsy, S. C.: The imprint of surface fluxes and transport on variations in total column carbon dioxide, Biogeosciences, 9, 875891, doi:10.5194/bg-9-875-2012, 2012.

Marquis, M. and Tans, P.: Carbon Crucible, Science, 320, 460-461, doi:10.1126/science.1156451, 2008.

Messerschmidt, J., Macatangay, R., Notholt, J., Petri, C., Warneke, T., and Weinzierl, C.: Side by side measurements of $\mathrm{CO}_{2}$ by ground-based Fourier transform spectrometry (FTS), Tellus B, 62, 749-758, doi:10.1111/j.1600-0889.2010.00491.x, 2010.

Messerschmidt, J., Geibel, M. C., Blumenstock, T., Chen, H., Deutscher, N. M., Engel, A., Feist, D. G., Gerbig, C., Gisi, M., Hase, F., Katrynski, K., Kolle, O., Lavrič, J. V., Notholt, J., Palm, M., Ramonet, M., Rettinger, M., Schmidt, M., Sussmann, R., Toon, G. C., Truong, F., Warneke, T., Wennberg, P. O., Wunch, D., and Xueref-Remy, I.: Calibration of TCCON column-averaged $\mathrm{CO}_{2}$ : the first aircraft campaign over European TCCON sites, Atmos. Chem. Phys., 11, 10765-10777, doi:10.5194/acp-11-10765-2011, 2011.

Mikaloff Fletcher, S. E., Gruber, N., Jacobson, A. R., Gloor, M., Doney, S. C., Dutkiewicz, S., Gerber, M., Follows, M., Joos, F., Lindsay, K., Menemenlis, D., Mouchet, A., Müller, S. A., and Sarmiento, J. L.: Inverse estimates of the oceanic sources and sinks of natural $\mathrm{CO}_{2}$ and the implied oceanic carbon transport, Global Biogeochem. Cy., 21, GB1010, doi:10.1029/2006GB002751, 2007.

Morino, I., Uchino, O., Inoue, M., Yoshida, Y., Yokota, T., Wennberg, P. O., Toon, G. C., Wunch, D., Roehl, C. M., Notholt, J., Warneke, T., Messerschmidt, J., Griffith, D. W. T., Deutscher, N. M., Sherlock, V., Connor, B., Robinson, J., Sussmann, R., and Rettinger, M.: Preliminary validation of column-averaged volume mixing ratios of carbon dioxide and methane retrieved from GOSAT short-wavelength infrared spectra, Atmos. Meas. Tech., 4, 1061-1076, doi:10.5194/amt-4-1061-2011, 2011.

Olivier, J. G. J. and Berdowski, J. J. M.: The Climate System, chap. Global emissions sources and sinks, 33-78, Publishers/Swets \& Zeitlinger Publishers, Lisse, The Netherlands, ISBN: 90-5809255-0, 2001.

Popa, M. E., Gloor, M., Manning, A. C., Jordan, A., Schultz, U., Haensel, F., Seifert, T., and Heimann, M.: Measure- ments of greenhouse gases and related tracers at Bialystok tall tower station in Poland, Atmos. Meas. Tech., 3, 407-427, doi:10.5194/amt-3-407-2010, 2010.

Rayner, P. J. and O'Brien, D. M.: The utility of remotely sensed $\mathrm{CO}_{2}$ concentration data in surface source inversions, Geophys. Res. Lett., 28, 175-178, doi:10.1029/2000GL011912, 2001.

Reuter, M., Bovensmann, H., Buchwitz, M., Burrows, J. P., Connor, B. J., Deutscher, N. M., Griffith, D. W. T., Heymann, J., Keppel-Aleks, G., Messerschmidt, J., Notholt, J., Petri, C., Robinson, J., Schneising, O., Sherlock, V., Velazco, V., Warneke, T., Wennberg, P. O., and Wunch, D.: Retrieval of atmospheric $\mathrm{CO}_{2}$ with enhanced accuracy and precision from SCIAMACHY: Validation with FTS measurements and comparison with model results, J. Geophys. Res., 116, D04301, doi:10.1029/2010JD015047, 2011.

Rödenbeck, C.: Estimating $\mathrm{CO}_{2}$ sources and sinks from atmospheric mixing ratio measurements using a global inversion of atmospheric transport, Technical report 6, Max Planck Institute for Biogeochemistry, Jena, 2005.

Rödenbeck, C., Houweling, S., Gloor, M., and Heimann, M.: $\mathrm{CO}_{2}$ flux history 1982-2001 inferred from atmospheric data using a global inversion of atmospheric transport, Atmos. Chem. Phys., 3, 1919-1964, doi:10.5194/acp-3-1919-2003, 2003.

Rödenbeck, C., Conway, T. J., and Langenfelds, R. L.: The effect of systematic measurement errors on atmospheric $\mathrm{CO}_{2}$ inversions: a quantitative assessment, Atmos. Chem. Phys., 6, 149161, doi:10.5194/acp-6-149-2006, 2006.

Rodgers, C. D. and Connor, B. J.: Intercomparison of remote sounding instruments, J. Geophys. Res., 108, 4116, doi:10.1029/2002JD002299, 2003.

Rothman, L., Gordon, I., Barbe, A., Benner, D., Bernath, P., Birk, M., Boudon, V., Brown, L., Campargue, A., Champion, J.-P., Chance, K., Coudert, L., Dana, V., Devi, V., Fally, S., Flaud, J.M., Gamache, R., Goldman, A., Jacquemart, D., Kleiner, I., Lacome, N., Lafferty, W., Mandin, J.-Y., Massie, S., Mikhailenko, S., Miller, C., Moazzen-Ahmadi, N., Naumenko, O., Nikitin, A., Orphal, J., Perevalov, V., Perrin, A., Predoi-Cross, A., Rinsland, C., Rotger, M., Simecková, M., Smith, M., Sung, K., Tashkun, S., Tennyson, J., Toth, R., Vandaele, A., and Auwera, J. V.: The HITRAN 2008 molecular spectroscopic database, J. Quant. Spectrosc. Ra., 110, 533-572, doi:10.1016/j.jqsrt.2009.02.013, 2009.

Stephens, B. B., Gurney, K. R., Tans, P. P., Sweeney, C., Peters, W., Bruhwiler, L., Ciais, P., Ramonet, M., Bousquet, P., Nakazawa, T., Aoki, S., Machida, T., Inoue, G., Vinnichenko, N., Lloyd, J., Jordan, A., Heimann, M., Shibistova, O., Langenfelds, R. L., Steele, L. P., Francey, R. J., and Denning, A. S.: Weak Northern and Strong Tropical Land Carbon Uptake from Vertical Profiles of Atmospheric $\mathrm{CO}_{2}$, Science, 316, 1732-1735, doi:10.1126/science.1137004, 2007.

Takahashi, T., Sutherland, S., Sweeney, C., Poisson, A., Metzl, N., Tilbrook, B., Bates, N., Wanninkhof, R., Feely, R., Sabine, C., Olafsson, J., and Nojiri, Y.: Global sea-air $\mathrm{CO}_{2}$ flux based on climatological surface ocean $p \mathrm{CO}_{2}$, and seasonal biological and temperature effects Global sea-air $\mathrm{CO}_{2}$ flux based on climatological surface ocean $p \mathrm{CO}_{2}$, and seasonal biological and temperature effects, Deep-Sea Res. Pt. II, 49, 1601-1622, 2002.

Washenfelder, R., Toon, G., Blavier, J.-F., Yang, Z., Allen, N., Wennberg, P., Vay, S., Matross, D., and Daube, B.: Carbon dioxide column abundances at the Wisconsin Tall Tower site, J. 
Geophys. Res., 111, 1-11, doi:10.1029/2006JD007154, 2006.

White, M. A., Thornton, P. E., Running, S. W., and Nemani, R. R.: Parameterization and Sensitivity Analysis of the BIOME-BGC Terrestrial Ecosystem Model: Net Primary Production Controls, Earth Interact., 4, 1-85, doi:10.1175/10873562(2000)004<0003:PASAOT > 2.0.CO;2, 2000.

Wunch, D., Toon, G. C., Wennberg, P. O., Wofsy, S. C., Stephens, B. B., Fischer, M. L., Uchino, O., Abshire, J. B., Bernath, P., Biraud, S. C., Blavier, J.-F. L., Boone, C., Bowman, K. P., Browell, E. V., Campos, T., Connor, B. J., Daube, B. C., Deutscher, N. M., Diao, M., Elkins, J. W., Gerbig, C., Gottlieb, E., Griffith, D. W. T., Hurst, D. F., Jiménez, R., Keppel-Aleks, G., Kort, E. A., Macatangay, R., Machida, T., Matsueda, H., Moore, F., Morino, I., Park, S., Robinson, J., Roehl, C. M., Sawa, Y., Sherlock, V., Sweeney, C., Tanaka, T., and Zondlo, M. A.: Calibration of the Total Carbon Column Observing Network using aircraft profile data, Atmos. Meas. Tech., 3, 1351-1362, doi:10.5194/amt3-1351-2010, 2010.
Wunch, D., Toon, G. C., Blavier, J.-F. L., Washenfelder, R. A., Notholt, J., Connor, B. J., Griffith, D. W. T., Sherlock, V., and Wennberg, P. O.: The Total Carbon Column Observing Network, Philos. T. R. Soc. A, 369, 2087-2112, doi:10.1098/rsta.2010.0240, 2011.

Yang, Z., Washenfelder, R., Keppel-Aleks, G., Krakauer, N., Randerson, J., Tans, P., Sweeney, C., and Wennberg, P.: New constraints on Northern Hemisphere growing season net flux, Geophys. Res. Lett., 34, L12807, doi:10.1029/2007GL029742, 2007. 